\title{
Evaluation of Microbiological and Compositional Quality of Raw Cow's Milk (Household and Bulk) in Lankapura, Polonnaruwa, Sri Lanka
}

\author{
G. D. D. K. Gunasena and B. A. M. P. Siriwardhana
}

\section{ABSTRACT}

Purpose: At present, in Lankapura, there is a tremendous development in dairy sector. But milk quality issues were raised by the milk consumers and producers who collected milk from Lankapura. Although, measures have been taken to increase the milk production, the quality of milk has not been thoroughly evaluated in area.

Research methodology: This study was carried out to evaluate the microbiological, compositional quality of cow's milk collected from small scale farmers (25) and bulk milk tanks ( 25 samples) in the study area and to collect data about knowledge of farmers on clean milk production practices.

Findings: According to the study, acidity, and average level of bacterial count of household milk production were $0.229 \pm 0.029 \%, 6.193 \pm 0.311 \log ^{10}$ CFU/ml respectively and for bulk milk production were $0.294 \pm 0.020 \%$, $6.6427 \pm 0.322 \log ^{10} \mathrm{CFU} / \mathrm{ml}$ respectively. The mean percentage of specific gravity, protein, fat, lactose and SNF for bulk milk samples were $1.029 \mathrm{~g} / \mathrm{ml}$, $2.740 \% \pm 0.0866, \quad 4.120 \% \pm 0.8065, \quad 4.040 \% \pm 0.1581, \quad 7.6476 \% \pm 0.34219$ respectively and for household's milk samples were $1.028 \mathrm{~g} / \mathrm{ml}, 2.792 \%$ $\pm 0.1706,4.360 \% \pm 0.7314,4.032 \% \pm 0.1973,7.5716 \% \pm 0.33726$ respectively. When considering management practices of farmers, only $38 \%$ farmers cleaned the milking place. Only $28 \%$ of farmers maintained proper records. The results indicated that microbiological and compositional quality (except milk fat) were not in acceptable level for both household and bulk milk samples. For microbiological quality, there was a high statistical significance of bulk milk samples than the households.

Limitations: The quality of the milk was poor due to unhygienic practices and poor knowledge. Sample numbers were limited in this study, due to limited time period for this study. Larger individual coliform count could not be conducted due to limited manpower and laboratory resources.

Originality/ value: As long term solutions such as farmer education programmes, incentive based milk quality systems can be recommended.
Submitted : February 15, 2021

Published : February 25, 2021

ISSN: $2684-1827$

DOI: $10.24018 /$ ejfood.2021.3.1.249

\section{G. D. D. K. Gunasena}

Department of Microbiology, University of Kelaniya, Sri Lanka.

(e-mail: deepthi@kln.ac.lk)

B. A. M. P. Siriwardhana *

Department of Microbiology, University of Kelaniya, Sri Lanka.

(e-mail:

Pradeesiriwardhana_1983 @ ${ }^{\circledR}$ ahoo.com)

Keywords: compositional quality, cow's raw milk, hygienic practices microbiological quality.

\section{INTRODUCTION}

Dairying is an important source of subsidiary income generation for farmers in Lankapura, Sri Lanka. Small scale dairy farmers are primary sources of milk production [1]. New youth generation tend to use new dairy technology for their farms and the production is increasing in Lankapura. Average milk production in study area is 100,000 liters per month [2]. The safety and quality of the milk produced by them has to be guaranteed in order to enable them to retain and access conventional markets. Consumers are willing to pay more for improved milk safety and quality attributes [3]. Quality of the raw milk depends on its microbial density and compositional quality [4].

Cow milk is a highly nutritious food, and it is used for feeding infants and as a dietary supplement of children and adults. Milk is a good growth medium for microorganisms and prone to microbial contamination easily [5]. The microbial load of milk is a major factor in determining the quality of milk [6]. The high bacteria count and the presence of pathogenic bacteria in milk not only degrades the milk quality and shelf-life of milk or milk related products but also causes serious health threats to consumers [7].

Although milk from a healthy udder contain a very few bacteria and it picks up many bacteria from the time it leaves the teat of the cow until it is used for further processing [6]. Clean milk production depends on milking environment, the hygiene of milking person, cleanliness of udder, teats and containers that are used to store the milk. Contamination of milk after leaving the farm gate is largely due to poor milk handling practices and milk adulteration. [8]. Milk produced under hygienic conditions from healthy animals should not contain more than $5 \times 10^{5} \mathrm{CFU} / \mathrm{ml}$. [9]. So, it is necessary to 
get a clear idea about total bacterial number of raw milk and clean milk production is very important.

It is very important to assess the physio-chemical parameters on milk quality. Milk component levels are indicators of cow health, nutrition, and other management practices. It is nutritionally very important to consumers. As well as, it is economically important to farmers, milk producers and milk processors.

The principal constituents of cow milk are as follows. Water $87.8 \%(87.3-88.1 \%)$ and total solids (12.2\%). The total solids content is the mass percentage of the substances in the milk, comprising protein $3.3 \%$ (3.3-3.4), total fat 3.3\% (3.13.3), Lactose $4.7 \%$ (4.5- 5.1\%), Ash $0.7 \%$, calcium $0.13 \%$, phosphorus $0.10 \%$, potassium $0.14 \%$, chlorine $0.11 \%$, magnesium $0.01 \%$ and sodium $0.05 \%$. However, when different geographic regions are considered, the contribution from milk to the various nutritional components varies considerably [10]. So, this study was carried out to evaluate and compare the microbiological, compositional quality of raw cow's milk collected from small scale farmers and bulk milk tanks in the study area and to collect data about knowledge of small scale farmers on clean milk production practices.

\section{MATERIALS AND METHODS}

\section{A. Location of the Study Area}

The study was conducted in Lankapura divisional secretary division in Polonnaruwa district, Sri Lanka. Lankapura is situated in a plain valley of Mahaweli river in North Central Province in Sri Lanka and 216 kilometers away from Colombo. Area coverage is $184 \mathrm{~km}^{2}$ and Population is 42943 [11]. Lankapura is geographically situated at temperate region, making them suitable for dairy farming in the locality. The normal temperature is $28^{\circ} \mathrm{C}$.

\section{B. Milk Sampling}

A total number of fifty milk samples were collected from eleven small scale dairy farmers ( 25 samples) and eleven bulk milk tanks (25 samples) of milk collecting centers in Lankapura. The study was carried out from March to September 2018.

Only morning raw milk samples were collected from local and cross bred cows. Milk samples were collected within 1$1 \frac{1}{2}$ hours after milking from the milking cans, containers of households and bulk milk tanks of dairy cooperatives. Prior to collection of individual samples, physical appearance of milk was examined (any dust, hair, fecal particles, colour and odour).

Milk in milking cans, containers and bulk milk tanks was mixed using the plunger and milk was collected using dippers. Samples were collected into sterilized universal bottles $(250 \mathrm{ml})$ aseptically. All the sample bottles were properly labelled, stoppered, and transported to the laboratory in an ice packed cooler box. They were transported to the Veterinary Investigation Centre, Gallella, Polonnaruwa within one hour after sampling. The storage temperature after sampling was reached as quickly as possible and maintained between 0 and $4{ }^{\circ} \mathrm{C}$. Chemical and microbiological analysis was done within six hours after sampling. All the samples were pre heated to room temperature before testing.
A total of fifty milk samples were evaluated. (25 households and 25 from milk cooperatives among those surveyed). All laboratory tests were done at the Veterinary Investigation Centre, Gallella, Polonnaruwa.

\section{Method}

A semi structured questionnaire was used to collect data about livestock, feed, milk handling and quality control and record keeping through a single visit survey. Two hundred dairy farmers were selected randomly with a sample size of ten farmers by 20 gramaniladhari divisions

\section{Microbiological Analysis}

The microbiological tests were Standard plate count (SPC) test, titratable acidity test, alcohol test, and clot on boiling test and Resazurin test.

\section{E. Standard Plate Count (SPC)}

The total bacterial count was measured by adding $1 \mathrm{ml}$ of milk sample into sterile test tube having $9 \mathrm{ml}$ of $0.1 \%$ peptone solution. It was thoroughly mixed and serially diluted up to $1: 10^{-7}$. One ml diluted sample was poured plated using 15-20 $\mathrm{ml}$ of Standard Plate Count Agar (oxoid) which was prepared according to the guidelines given by the manufacturers and sterilized by autoclaving at $121^{\circ} \mathrm{C}$ for 15 minutes. The plated samples were allowed to solidify and then incubated at $30^{\circ} \mathrm{C}$ for 48 hours under aerobic condition [12]. Colony counts were made and the number of microorganisms (colony forming units) per $\mathrm{ml}$ of milk was calculated using the following formula [13].

$$
\text { Count }=\mathrm{Sk} /(\mathrm{n} 1+0.1 \mathrm{n} 2) \times \mathrm{d}
$$

where

$\mathrm{Sk}=$ sum of all colonies counted (between 10 and 300), $\mathrm{n} 1=$ number of plate from the lowest dilution used for computing the count, $\mathrm{n} 2=$ number of plates in the next dilution factor used for computing the count,

$\mathrm{d}=$ reciprocal of the dilution factor of the lowest dilution used for computing the count corresponding to $\mathrm{n} 1$.

\section{F. Titratable acidity test}

$10 \mathrm{ml}$ of milk was pipetted into a beaker and then 3-5 drops of 0.5 percent phenolphthalein indicator was added into the milk. Then the sample was titrated with $0.1 \mathrm{~N} \mathrm{NaOH}$ solution until definite pink colour persists [9]. Percent of lactic acid was calculated according to the following formula.

$$
\text { Lactic acid }(\%)=\left(\frac{m l \frac{N}{10} \text { alkali } \times 0.009}{m l \text { of sample }}\right) \times 100
$$

\section{G. Alcohol Test}

Five $\mathrm{ml}$ of milk and $5 \mathrm{ml}$ of 68 percent alcohol (ethanol) were placed in a test tube. The test tube was inverted several times with the thumb held tightly over the open end of the tube. Then the tube was examined for formation of curd particles [9]. 


\section{H. Clot on Boiling Test}

Five $\mathrm{ml}$ of milk was placed in a test tube and it was placed in a boiling water bath for five minutes. Then, the test tube was carefully removed from the water bath and examined for the presence of floccules [9].

\section{Resazurin Test}

The solution of Resazurin was prepared by adding one tablet to $50 \mathrm{ml}$ of distilled sterile water. (0.005\% resazurin). Resazurin solution must not be exposed to sunlight and it should not be used for more than eight hours, because it loses the strength. Milk sample was mixed well and $10 \mathrm{ml}$ of milk was added to a sterile test tube. One milliliter of resazurin solution was added to the same test tube. Milk and dye were mixed gently and incubated at $37{ }^{\circ} \mathrm{C}$ water bath. Resazurin test was carried out as 10 min test and $1 \mathrm{hr}$ test test [14].

\section{J. Chemical Characteristics of Raw Milk}

The raw milk was analyzed for temperature, protein, fat, lactose and solid non-fat by using MASTER PRO milk analyzer according to the instructions of the manufacturer.

\section{K. Specific Gravity}

Fresh milk samples were filled sufficiently in a cylinder; lactometer was held by the tip and inserted into the milk. The lactometer was allowed to float freely until it reached equilibrium. Then the reading at the bottom of the meniscus was recorded. Immediately, thermometer was inserted, and the temperature of the milk was recorded. The following formula was used to calculate the milk specific gravity.

$$
\text { Specific gravity }=(\mathrm{L} / 1000)+1
$$

where L - corrected lactometer reading at a given temperature.

i.e., for every degree above $60{ }^{\circ} \mathrm{F}, 0.1$ degree was added, but for every degree below $60{ }^{\circ} \mathrm{F}, 0.1$ degree was subtracted from the lactometer reading [15].

\section{Statistical Analysis}

Mean values and standard deviations were calculated for total bacterial counts, acidity of milk, milk fat, Protein, SNF (Solid Non Fat) and specific gravity of milk samples which were collected from households and bulk milk tanks. Descriptive statistics such as mean, standard deviation, percentage and range were used to compute some of the data using SPSS 22 version. Separation of mean values and standard values were carried out by using one sample $\mathrm{T}$ test. For comparison of house hold and bulk milk samples ANOVA and box plot were used.

\section{RESULTS AND DISCUSSION}

The findings showed that most of the farmers who practiced dairy farming were male $(80 \%)$ of age $20-40$ years (75\%). 90\% were married. $75 \%$ have completed their education up to Ordinary Level. In Lankapura, 54\% of farmers did not have permanent cattle sheds. Reference [16] reported that during production and processing of milk, important sources of microbial contamination were milk pail, hands of milking person and machines. They reported that the highest mean total count was obtained from milker's hands. In Lankapura, 90\% farmers had washed their hands before milking and $84 \%$ farmers washed the udder of the cow before milking, but $48 \%$ of farmers used opened water sources like tanks and rivers and they were not protected water sources. $8 \%$ of farmers got water from protected wells. Reference [17] suggested that the hygienic practices followed during the production of milk at the point of production (farmers' level) needs an improvement with regard to reduction in microbial count and overcoming the impact of the harmful pathogens. Reference [18] reported that about $43.9 \%$ of the dairy farm owners used common towel for all cows to dry the udder and about $47.7 \%$ dairy owners used bare hand to dry the udder. In Lankapura, only $52 \%$ of farmers used to dry the udder before milking, but among that, $85 \%$ farmers used common towel and old cloths to dry the udder. Using common towel and old cloths bacterial contamination can be happened easily. Only $8 \%$ of farmers used new cloths and tissues. $96 \%$ of farmers did hand milking and only $4 \%$ farmers used milking machines.

Only $10 \%$ farmers used disinfectant solutions to disinfect udder before milking and $90 \%$ farmers did not disinfect the udder. Only $38 \%$ farmers cleaned the milking place. Cleaning of plastic and glass bottles is difficult due to the narrow neck restricting access. Microorganisms can easily grow in moist milky residues in such bottles [19], [20]. Out of 200 farmers, $54 \%$ people used plastic containers to carry milk and $46 \%$ used aluminum cans. Only $28 \%$ maintained proper records and $72 \%$ did not have.

\section{A. Microbiological Tests}

The Chemical composition and other laboratory analysis of bulk samples and house hold milk samples were separately recorded to determine.

\section{B. Titrtabale Acidity Tests}

Data pertaining to acidity of household milk samples and bulk milk samples have been shown in figure 1; while its statistical evaluation is given in Table 1 .

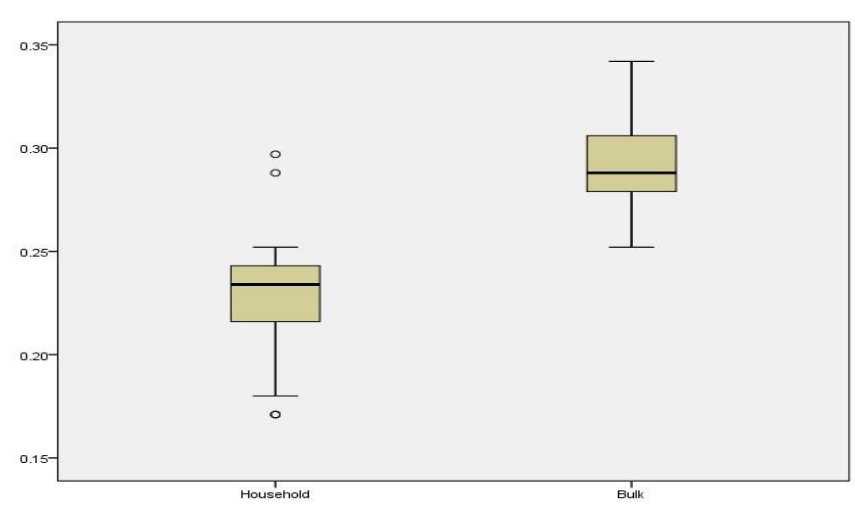

Fig 1. Comparison of acidity in household milk samples and bulk milk samples. According to the above box plot, acidity concentration of bulk milk production was much higher than the acidity concentration in household milk production.

The above box plot shows a significant difference of acidity between the bulk milk samples and household milk samples. According to the above box plot, acidity 
concentration of bulk milk production was much higher than the acidity concentration in household milk production. Additionally, it was seen that acidity concentration of household milk samples are vary within $0.171 \%$ and $0.293 \%$. Acidity concentrations of bulk milk samples are varying within $0.252 \%$ and $0.324 \%$.

TABLE 1: DESCRIPTIVE STATISTICS FOR ACIDITY (\%) OF DIFFERENT MILK

\begin{tabular}{ccccc}
\multicolumn{5}{c}{ SAMPLES } \\
\hline Source & Mean & $\begin{array}{c}\text { Standard } \\
\text { deviation }\end{array}$ & $\begin{array}{c}\text { T-value } \\
\left(\mathrm{H}_{0}: \text { Mean }\right. \\
\leq 0.2 \%)\end{array}$ & P-Value \\
\hline $\begin{array}{c}\text { Household } \\
\text { Milk } \\
\text { Bulk Milk }\end{array}$ & $0.229 \%$ & 0.029 & $5.066^{* *}$ & $\mathrm{P} \leq 0.001$ \\
\hline
\end{tabular}

** Significant at $10 \%$.

According to the study average level of acidity of household milk production is $0.229 \%$ and the average level of acidity of bulk milk production is $0.294 \%$. The study was generally demonstrated that acidity of bulk milk production was higher than that the acidity of household milk production.

According to reference [21], normal fresh milk has an apparent acidity of $0.14 \%$ to $0.16 \%$ as lactic acid.

So, for the acceptances of milk quality, acidity concentration should be lie within the range of $0.1 \%$ and $0.2 \%$. For that the mean intake of each household milk samples and bulk milk samples were tested whether the mean value is less than $0.2 \%$. Results indicate that the acidity level was not less than $0.2 \%$ for both household milk and bulk milk production. Acidity level of milk in the study area was higher than accepted level. As well as there is a high statistical significance between the household milk and bulk milk samples.

TABLE 2: ANALYSIS OF VARIANCE FOR ACIDITY

\begin{tabular}{|c|c|c|c|c|c|}
\hline & $\begin{array}{l}\text { Sum of } \\
\text { Squares }\end{array}$ & df & Mean Square & $\mathrm{F}$ & Sig. \\
\hline Between Groups & .051 & 1 & .051 & $81.328 * *$ & $\mathrm{P} \leq 0.001$ \\
\hline Within Groups & .030 & 48 & .001 & & \\
\hline Total & .082 & 49 & & & \\
\hline
\end{tabular}

** Significant at 5\%.

The above Table 2 depicts the comparison of acidity between household milk production and bulk milk production. A highly statistical significance was seen between household milk production and bulk milk production. It is revealed from the work that acidity of bulk milk production was much higher than that of household milk production.

\section{Alcohol Test} 3.

The results pertaining to the alcohol test are shown in Table

TABLE 3: COMPARISON OF RESUlts OF AlCOHOL TEST FOR BULK MiLK PRODUCTION AND HOUSEHOLd MILK PRODUCTION

\begin{tabular}{cccccc}
\multicolumn{6}{c}{ PRODUCTION AND HOUSEHOLD MILK PRODUCTION } \\
\hline \multirow{2}{*}{ Parameters } & $\begin{array}{c}\text { Bulk } \\
\text { Milk } \\
\text { N=25 }\end{array}$ & $\begin{array}{c}\text { Household } \\
\text { Milk N=25 }\end{array}$ & $\begin{array}{c}\text { Chi- } \\
\text { Square } \\
\text { Value }\end{array}$ & $\begin{array}{c}\text { P- } \\
\text { Value }\end{array}$ \\
\hline Alcohol & Positive & $\begin{array}{c}25 \\
(100 \%)\end{array}$ & $9(36 \%)$ & & \\
Concentration & $\begin{array}{c}\text { Slightly } \\
\text { Positive }\end{array}$ & $0(0 \%)$ & $5(20 \%)$ & $23.529 * *$ & P $\leq$ \\
& Negative & $0(0 \%)$ & $11(44 \%)$ & & 0.001 \\
\hline$* *$ Significant at $5 \%$ & & &
\end{tabular}

According to the above results, each sample of in bulk milk samples $(100 \%)$ are positive with alcohol test whereas $56 \%$ in household milk samples. Each bulk milk production contains the high acid concentration, while $36 \%$ of household milk production containing the high acid concentration. A highly statistical significance was seen for alcohol test between bulk milk samples and household milk samples. The results of alcohol test for household milk samples showed better quality compared to the bulk milk samples.

The first clotting due to acid development can first be seen at $0.21-0.23 \%$ of Lactic acid. Proteins in milk that has become sour (i.e., because of lactic acid formation) will coagulate when mixed with alcohol [22].

When the positive for alcohol test, it indicates the high microbial load.

\section{Standard Plate Count Test}

The standard Plate count test has been reported to be generally accepted as the most accurate and informative method of testing the bacteriological quality of milk [23], [24].

Data pertaining to bacterial count of household and bulk milk samples have been shown in Table 4 and its statistical evaluation is given in Table 5.

TABLE 4: DESCRIPTIVE STATISTICS FOR SAMPLE PLATE COUNT

\begin{tabular}{ccccc}
\hline Source & $\begin{array}{c}\text { Mean } \\
(\log 10 \mathrm{CFU} / \mathrm{ml})\end{array}$ & $\begin{array}{c}\text { Standard } \\
\text { deviation }\end{array}$ & $\begin{array}{c}\text { T-value } \\
\left(\mathrm{H}_{0}: \text { Mean }\right. \\
\leq 5.699)\end{array}$ & $\begin{array}{c}\mathrm{P}- \\
\text { Value }\end{array}$ \\
\hline $\begin{array}{c}\text { Household } \\
\text { Milk }\end{array}$ & 6.1930 & 0.311 & $7.938^{* *}$ & $\begin{array}{c}\mathrm{P} \leq \\
0.001 \\
\mathrm{P} \leq\end{array}$ \\
Bulk Milk & 6.6427 & 0.322 & $14.646^{* *}$ & \begin{tabular}{c}
0.001 \\
\hline
\end{tabular}
\end{tabular}

** Significant at $10 \%$.

The mean intake of standard plate counts was compared between household milk and bulk milk samples. It was seen that mean of household milk samples were vary within 5.43 and $6.46 \log _{10} \mathrm{CFU} / \mathrm{ml}$. Mean value of bulk milk samples were varying within 6.38 and $7.11 \log _{10} \mathrm{CFU} / \mathrm{ml}$. According to the study average levels of bacterial count of household milk production and bulk milk productions are 6.19 and 6.64 $\log _{10} \mathrm{CFU} / \mathrm{ml}$ respectively. The study was generally demonstrated that bacterial count of bulk milk production was higher than the bacterial count of household milk production.

According to reference [25], total plate count of milk collected from Makandura area, Sri lanka was $2.3 \times 10^{6} \mathrm{cfu} / \mathrm{ml}$ and it was similar to that reported in the study in Jaffna, Sri Lanka, by reference [26].According to the reference [27], the maximum number of SPC of milk was found in high risk chilling centers $(8.737 \mathrm{Log} 10 \mathrm{CFU} / \mathrm{ml})$ while the minimum was recorded in transportation vessels $\left(7.438 \log _{10} \mathrm{CFU} / \mathrm{ml}\right)$.

Additionally, for the acceptances of milk quality, bacterial count should be less than $5 \times 10^{5} \mathrm{CFU} / \mathrm{ml}$ (5.699 $\log _{10}$ CFU/ml) [09]. According to Sri Lanka Standard Institute 1983 , expected standard is less than $30,000 \mathrm{cfu} / \mathrm{ml}$.

In this study, the mean value of each household milk samples, and bulk milk samples were tested whether the mean value for bacterial counts were less than $5.699 \log _{10} \mathrm{CFU} / \mathrm{ml}$ [9]. 


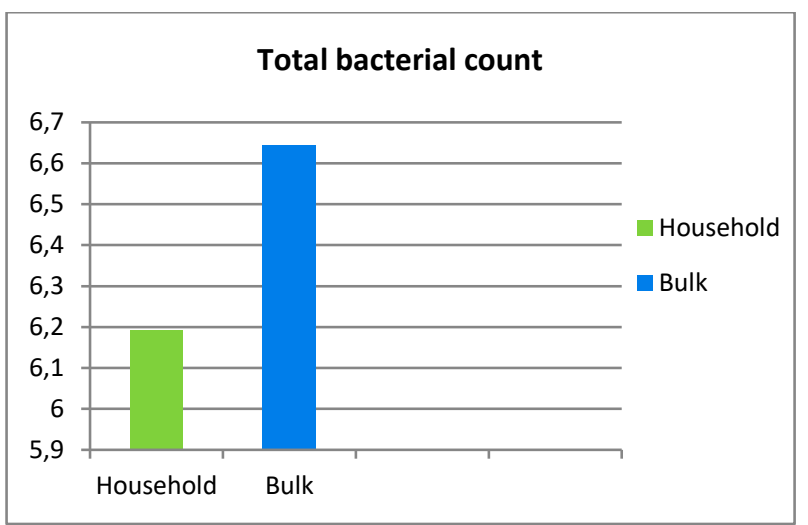

Fig. 2. Comparison for household and bulk milk samples for standard plate count test. The bacterial count of bulk milk production was higher than that the bacterial count of household milk production.

TABLE 5: ANOVA FOR STANDARD PLATE COUNT

\begin{tabular}{cccccc}
\hline & $\begin{array}{c}\text { Sum of } \\
\text { Squares }\end{array}$ & df & $\begin{array}{c}\text { Mean } \\
\text { Square }\end{array}$ & F & Sig. \\
\hline Between & & 1 & 2.528 & & P $\leq 0.001$ \\
Groups & 2.528 & & & $25.199 * *$ & \\
Within & 4.815 & 48 & .100 & & \\
Groups & 7.343 & 49 & & & \\
Total & & 49 & & & \\
\hline
\end{tabular}

** Significant at $5 \%$

Above Table 5 depicts the comparison between household and bulk milk production. A highly statistical significance was seen between household milk production and bulk milk production.

The reference [28] reported that application of a milk quality payment system based on total bacterial counts and somatic cell counts of raw milk was effective in improving raw milk quality in Korea. They reported that the proportion of herds in the first grade of total bacterial counts $(<100,000 \mathrm{CFU} / \mathrm{ml})$ after application of the milk payment system improved from $26.7 \%$ to $85.4 \%$ and decreased from $54.6 \%$ to $6.1 \%$ in third and fourth grade of total bacterial counts (>250,000 CFU/ml), respectively.

\section{E. Resazurin Test}

TABLE 6: COMPARISON OF RESULTS OF RESAZURIN TEST BETWEEN BULK MiLK PRODUCTION AND HOUSEHOLD MILK PRODUCTION

\begin{tabular}{cccccc}
\hline \multirow{2}{*}{ Parameters } & & $\begin{array}{c}\text { BulkMilk } \\
\text { N=25 }\end{array}$ & $\begin{array}{c}\text { Household } \\
\text { Milk N=25 }\end{array}$ & $\begin{array}{c}\text { Chi- } \\
\text { Square } \\
\text { Value }\end{array}$ & $\begin{array}{c}\text { P- } \\
\text { Value }\end{array}$ \\
\hline \multirow{4}{*}{ Test Colour } & Light Blue & $0(0 \%)$ & $3(12 \%)$ & & \\
& Purple & $\begin{array}{c}24 \\
(100 \%)\end{array}$ & $22(88 \%)$ & $3.191^{\mathrm{NS}}$ & 0.074 \\
& Purple Pink & 01 & & & \\
\hline
\end{tabular}

NS -Not Significant.

In Table 7, the colour change and numerical score value ranging from 1 to 6 can be seen. It uses the indicator resazurin to measure the bacteriological quality of milk. The majority of the organisms in milk are capable of reducing and decolorizing the resazurin dye. When bacteria grow in the milk they utilize oxygen, the rate of removal or reduction is proportional to the keeping quality.
TABLE 7: READING AND RESULTS (10 MINUTE RESAZURIN TEST)

\begin{tabular}{ccc}
\hline Disc No & Colour & Grade of milk \\
\hline 6 & Blue & Excellent \\
5 & Light Blue & Very Good \\
4 & Purple & Good \\
3 & Purple pink & Fair \\
2 & Light pink & Poor \\
1 & Pink & Bad \\
0 & White & Very bad \\
\hline
\end{tabular}

(Source - Milk Testing and Payment Systems Resource Book - Practical $=$ guide, 2009).

According to the results, none of the bulk milk product performed in blue colour for resazurin test, while few household milk productions $(12 \%)$ performed in blue colour for resazurin test.12\% household milk samples were very good. Samples in bulk milk production were purple colour and purple pink colour for resazurin test, while in most household milk production $(88 \%)$ were purple colour for resazurin test. $88 \%$ household milk samples were good.

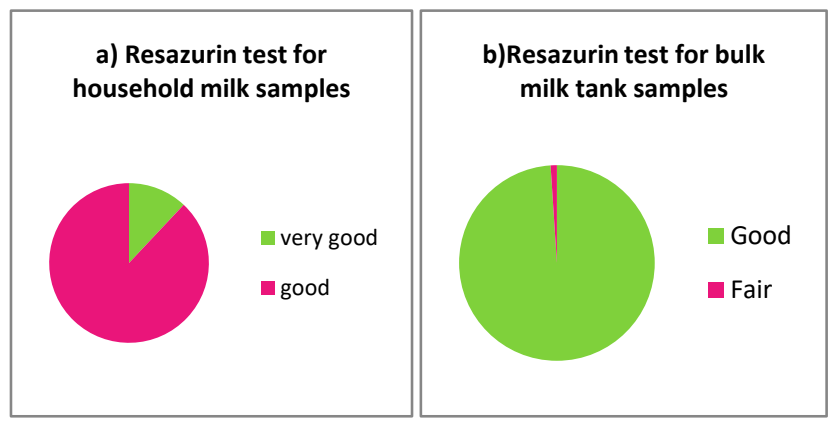

Fig. 3. Resazurin test for a) household and b) bulk milk samples.

According to Fig. 3, none of the bulk milk product performed in blue colour for resazurin test, while few household milk productions $(12 \%)$ performed in blue colour for resazurin test. $12 \%$ household milk samples are very good. Sample in bulk milk production was performed purple colour and purple pink colour for resazurin test, while in most household milk production (88\%) was performed purple colour for resazurin test. $88 \%$ household milk samples are good.

Fig. 3 shows that the result was generally demonstrated that none of the bulk milk production in excellent quality. But those are in acceptable good quality and fair.

According to the results, only few percent of household milk production was excellent quality, whereas most of the household milk productions were not excellent but acceptable good quality. The results indicated that milk quality of household milk production was comparatively better than the bulk milk production.

According to the alcohol, acidity, and standard plate count tests, they indicated that there was a high microbial load in the milk collected from Lankapura area. As well as microbial load of the bulk milk samples was higher than the household milk samples. That reflects the poor hygienic practices along the milking process. Cold chain throughout the process should be properly managed.

Extensive and semi intensive dairy management systems can be seen in Lankapura. In extensive system, there are no proper cattle sheds. So, animal lie down on the floor and easily udder can be infected with bacteria. That leads to mastitis. Poor cleaning practices can be a cause to increase bacterial load of milk. But milking machines are used by 
some farmers and microbial contamination is very less. Very few numbers of farmers use teat dipping disinfectant solutions to clean udder. Some farmers have very large herds in the jungle. There are no proper places for milking in the jungle. Therefore, microbial contamination can be happened easily. Lack of milking facilities exposes milk into contamination with manure and other dirties that might be in cattle sheds during the milking time.

Practices such as washing of hands with soap and warm water before milking, the washing of the udder using a dry clean cloth and daily removal of manure from the dairy shed were not done by majority of the farmers and this could have contributed to the good quality of the milk. Thorough cleaning of the udder followed by drying with a clean cloth was effective in reducing the number of bacteria in milk contributed from soiled teats [29]. There was a significant effect on application of hygiene practices prior to milking in total count and coliform count [30]. Microbial contamination of milk can be happened by soiling of teats with manure, mud, feeds, or bedding; organic bedding has been shown to harbor large numbers of microorganisms which often exceed $10^{8}$ to $10^{10}$ organisms per gram of bedding [29].

Milk production practices influenced the level of contamination at the farm level. Most farmers did not tie the cow's tail during milking. Tying of the tail is important in the local setting because cows carry a lot of dust or mud from the stable on their body. During milking, a lot of this dust is dislodged by the constant waving of the tail to drive way flies. This constitutes one of the most direct methods of milk contamination.

By using proper refrigerator facilities for storage and transportation of milk, the microbial load can be decreased. Vehicles which transport milk from the collection centers to the companies and sales out lets should have refrigerator facilities. As well as milk collecting centers should be established in easily accessible places.

Acidity and microbial load of bulk milk samples is significantly higher than the households. It was understood that there were inadequate sanitary practices occurring among the groups, milk brought in unsterile containers and travelling longer distance from the households and poorer transportation are seen as causative reasons for higher microbial loads. In Lankapura, some farmers transported milk using aluminum cans while some farmers used plastic containers. Stainless steel containers are recommended because they do not have adhesive properties and therefore easy to clean when compared with plastic containers. Most of the farmers do not wash their containers and this leads to the growth of harmful bacteria. It is very good to wash containers with hot water and soap and either hang them out to dry or place them on specially erected racks, a practice which also contributes to the good quality of the milk. Udder washing with warm water from protected source and then drying the udder with disposable paper towels ensures clean milk production

Microbiological quality of bulk tank is higher than the households. This may be due to poor hygiene in milk handling plus a prolonged holding time prior to delivery, providing a favorable environment for microbial growth [31]. The distance or time between milking, transportation and collection has been noted as a contributor to the microbiological quality of the milk sold by milk traders [32]. Bacterial growth in milk is most rapid after 2-3 hours post milking when they enter the log phase of rapid growth [33]. In a study conducted on the microbiological quality of milk in a region of Nepal by reference [34], the high total bacterial count was attributed to the distance between the milk collection units and the milk plants. It was also noted that some of the milk transporters took long time to transport milk to the cooling center. It has been reported that milk spoils within 3-4 hours after milking especially in hot environmental temperatures. Cooling of milk therefore is advocated to help in significantly reducing the multiplication of bacteria and in turn reducing spoilage [32].

The high load of bacterial count indicates the microbial contamination at every point of milk handling. To minimize the microbial contamination and to produce good quality milk, good health status of animals, hygienic practices during milking, storage and transportation should be maintained. Bulk milk quality checking should be done routinely. Proper standards should be established. Proper awareness programs should be initiated to educate the dairy farmers and milk producers.

\section{F. Specific Gravity}

Data pertaining to specific gravity of household milk samples and bulk milk samples have been shown in Fig. 4; while its statistical evaluation is given in Table 8 .

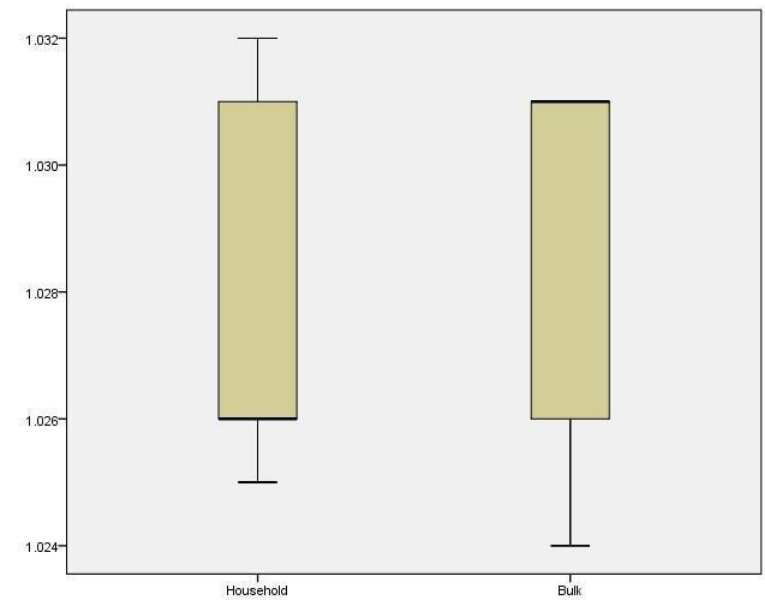

Fig. 4. Comparison of specific gravity in household milk samples and bulk milk samples. This figure shows that there is not a significant difference of specific gravity between the bulk milk samples and household milk samples.

TABLE 8: DESCRIPTIVE STATISTICS FOR SPECIFIC GRAVITY OF DIFFERENT

\begin{tabular}{ccccc}
\multicolumn{5}{c}{ MILK SAMPLES } \\
\hline Source & Mean & $\begin{array}{c}\text { Standard } \\
\text { deviation }\end{array}$ & $\begin{array}{c}\text { T-value } \\
\left(\mathrm{H}_{0}: \text { Mean } \leq\right. \\
1.032 \mathrm{~g} / \mathrm{ml})\end{array}$ & P-Value \\
\hline Household Milk & 1.028 & 0.0024 & $8.341^{\mathrm{NS}}$ & 0.06 \\
Bulk Milk & 1.029 & 0.0025 & $6.101^{\mathrm{NS}}$ & 0.05 \\
\hline
\end{tabular}

NS - Not Significant.

According to the study average level of specific gravity of household milk production is $1.028 \mathrm{~g} / \mathrm{ml}$ and the average level of specific gravity of bulk milk production is $1.029 \mathrm{~g} / \mathrm{ml}$. The study was generally demonstrated that specific gravity of bulk milk production was bit higher than that the specific gravity of household milk production (Fig. 5). According to the European Union quality standards for 
unprocessed whole milk, specific gravity ranges from 1.027$1.035 \mathrm{~g} / \mathrm{ml}$ with the mean value of $1.032 \mathrm{~g} / \mathrm{ml}$ [35]. According to reference [36], the higher value of specific gravity indicates skimming off fat whereas the lower value than normal value of specific gravity is indicative of addition of water.

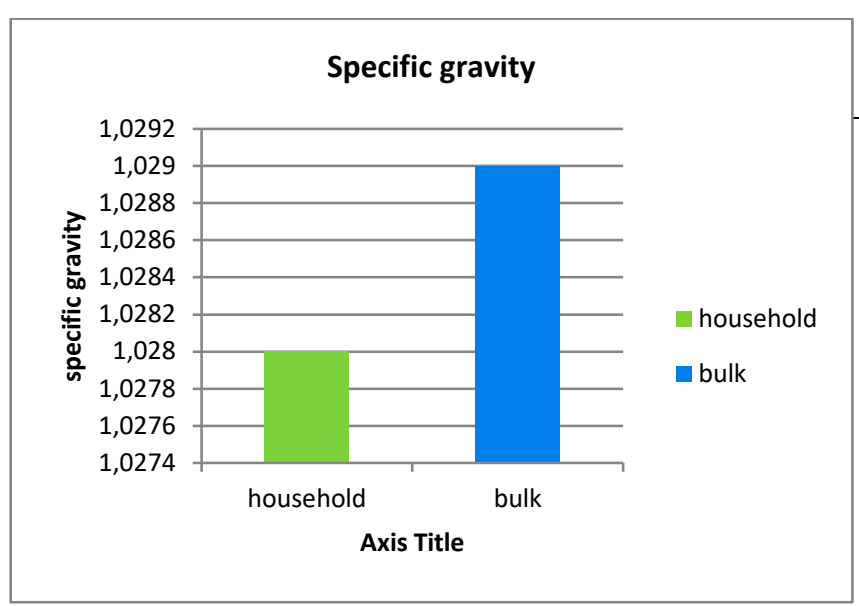

Fig 1. Comparison of specific gravity of household and bulk milk samples.

No statistically significant difference was seen in both household milk and bulk milk samples. Results indicate that the specific gravity was less than $1.032 \mathrm{~g} / \mathrm{ml}$ for both household milk and bulk milk production. The specific gravity in milk is lowered by addition of water and cream and is increased by addition of skim milk or removal of fat [37]. In this milk samples fat content is higher than the normal and SNF and protein content is lower than the normal. So, Specific gravity is lower than the accepted value.

\begin{tabular}{cccccc}
\multicolumn{6}{c}{ TABLE 9: ANALYSIS OF VARIANCE FOR SPECIFIC GRAVITY } \\
\hline & $\begin{array}{c}\text { Sum of } \\
\text { Squares }\end{array}$ df & Mean Square & F & Sig. \\
\hline $\begin{array}{c}\text { Between } \\
\text { Groups }\end{array}$ & .000 & 1 & .000 & $1.927^{\mathrm{NS}}$ & .172 \\
$\begin{array}{c}\text { Within } \\
\text { Groups Total }\end{array}$ & .000 & 48 & .000 & & \\
\hline
\end{tabular}

NS - Not Significant.

The above Table 9 depicts the comparison of specific gravity between household milk production and bulk milk production. The analysis of variance shows that the mean values for specific gravity were found to be no significant. According to the above results there is slight difference of specific gravity in between bulk milk production and household milk production. But in there is no difference in specific gravity in between bulk milk production and household milk production.

\section{G. Nutrition Concentration}

Table 10 shows that the comparison of the mean intake of nutrition concentration of the bulk milk production and household milk production. It was seen that mean value of protein and fat concentration were higher in household milk than the bulk milk production, while in case of lactose and SNF was much higher in bulk milk production than the household milk production. But according to the results, there is no significant difference was seen between the nutrition condition of bulk milk production and household milk production.

TABLE 10: COMPARISON OF MEANS OF NUTRITION CONCENTRATION BetweEn THE BulK MiLK PROdUCTION AND HOUSEHOLD MILK

\begin{tabular}{ccccc}
\hline \multicolumn{5}{c}{ PRODUCTION } \\
\hline Nutrition & $\begin{array}{c}\text { Bulk Milk } \\
(\text { mean } \pm \text { SD })\end{array}$ & $\begin{array}{c}\text { Household Milk } \\
(\text { mean } \pm \text { SD) }\end{array}$ & F-value & $\begin{array}{c}\text { P- } \\
\text { Value }\end{array}$ \\
\hline Fatein & $2.740 \pm 0.0866$ & $2.792 \pm 0.1706$ & $1.847^{\text {NS }}$ & 0.180 \\
Lactose & $4.120 \pm 0.8065$ & $4.360 \pm 0.7314$ & $1.135^{\mathrm{NS}}$ & 0.292 \\
SNF & $4.040 \pm 0.1581$ & $4.032 \pm 0.1973$ & $0.025^{\mathrm{NS}}$ & 0.875 \\
\hline & $7.6476 \pm 0.34219$ & $7.5716 \pm 0.33726$ & $0.626^{\mathrm{NS}}$ & 0.433 \\
\hline
\end{tabular}

NS - Not Significant.

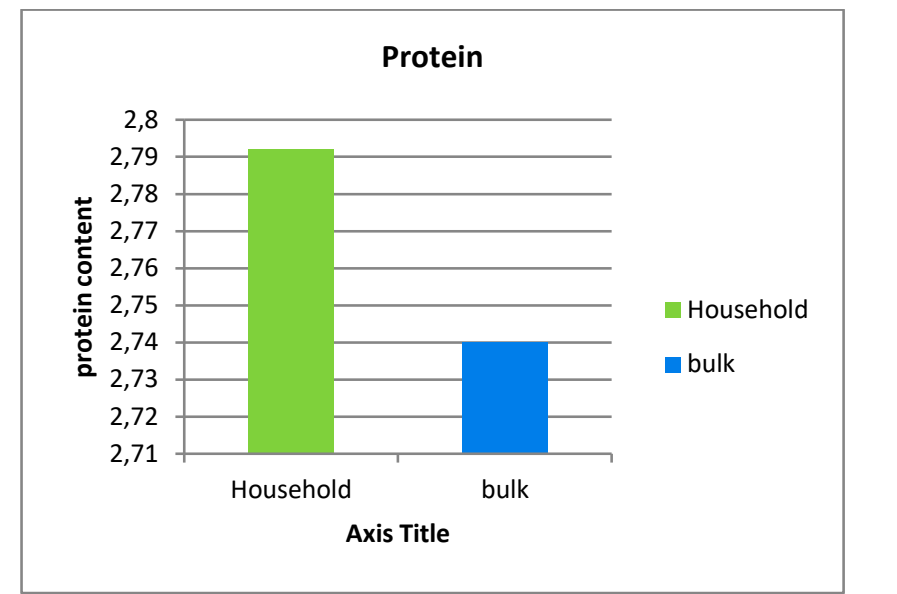

Fig. 6. Comparison of protein content of household and bulk milk samples.

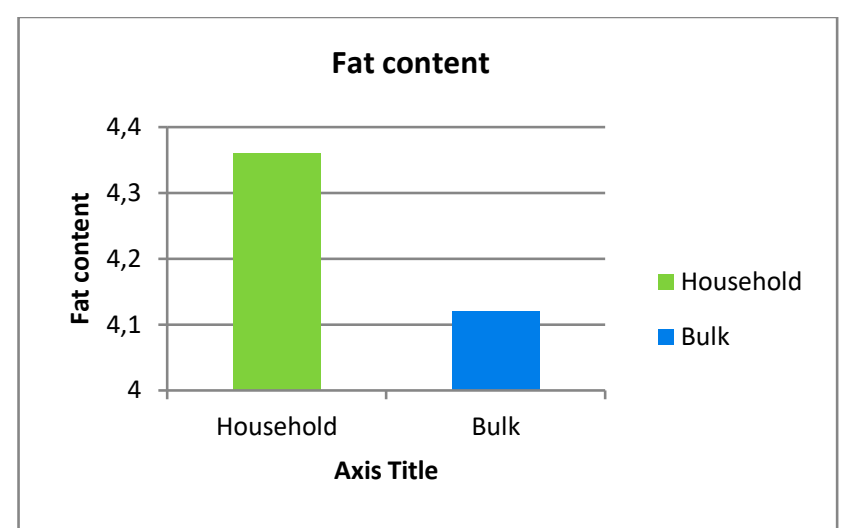

Fig. 2. Comparison of fat content of bulk and household milk samples.

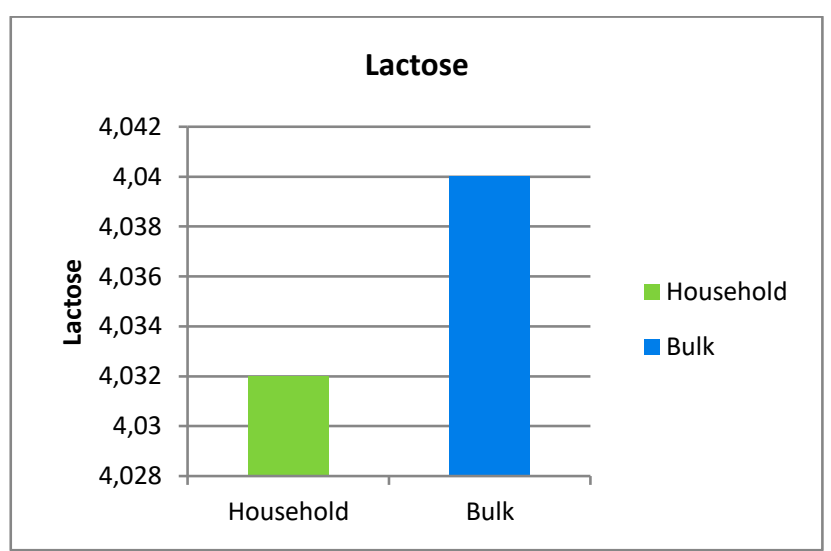

Fig. 3. Comparison of lactose content of household and bulk milk samples. 


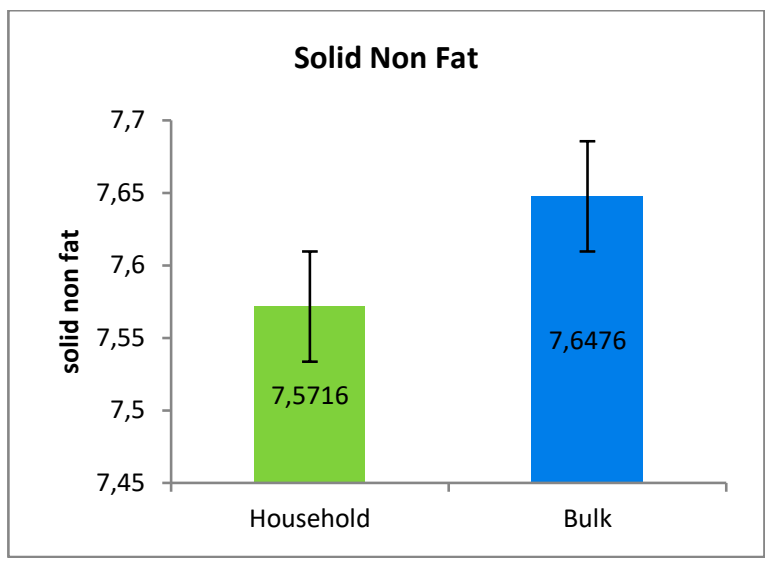

Fig. 9. Comparison of SNF of household and bulk milk samples.

The composition of milk marketed nationally has been rather constant over the last 15 years, averaging 3.6 percent fat, 3.2 percent protein, and 4.7 percent lactose. The mean intake of nutrition concentration was compared between bulk milk production and household milk production according to the milk market values [38]. According to Malcolm and Paul, cow milk contains $12.5 \%$ total solids, $3.8 \%$ fat, $8.7 \%$ solid nonfat, $4.6 \%$ lactose, $0.8 \%$ ash, $0.2 \%$ NPN (Non Protein Nitrogen), $3.1 \%$ protein and $87.5 \%$ water. According to West Pakistan Pure food rules market milk shall contain not less than $3.5 \%$ fat and $8.5 \%$ solid non-fat (SNF).

In dairy production, especially cheese production, raw milk composition has a significant influence on the yield and quality of the final product [39]. Milk composition can vary for different reasons. Factors affecting milk composition can be categorized into genetic, physiological, environmental, and pathological. Most of the components in milk are affected by pathological changes, mastitis in particular [40].

Variations in fat content are highly dependent on milking and feeding. The residual milk is high in fat content and during the milking procedure the fat content increases. Therefore, the fat content in milk is affected by udder emptying during milking [41]. According to reference [42], milk of Jersy breeds contains higher content of fat than other breeds. According to reference [09], Jersey and Guernsey breeds give milk with about $5 \%$ fat while the milk of shorthorns and Friesians contains about $3.5 \%$ fat. In Lankapura area, there are more Jersy cross bred cattle. So, fat content of milk samples is higher than the accepted value. Milk composition varies considerably among breeds of dairy cattle [43]. The variation due to difference in breed, feeding and management practice [21].

It has been reported that SNF contents of cattle milk can be reduced by diseases particularly mastitis and underfeeding [44]. According to the reference [45], the difference of SNF could be due to feeding practices, season, milking methods and lactation period.

Protein and lactose contents of milk can vary due to breed, age, nutrition, season, milking method and lactation period. Cows in developing countries are "underfed" and hence suffer from "Negative Energy Balance". They also suffer from Negative Protein Balance, Negative Water Balance, Negative volume balance and Negative mineral balance [46].

Microbial activities such as degradation of proteins and lipids of milk can also change the composition of milk [21]. Microbial load is high in bulk tank than the household milk samples. So, Protein and fat contents are low in bulk milk tanks.

TABLE 11: COMPARISON OF MEANS OF NUTRITION CONCENTRATION OF OBTAINED Milk SAMPLES WITH ACCEPTED VALUES

\begin{tabular}{cccc}
\hline Nutrition & $\begin{array}{c}\text { Bulk Milk } \\
(\text { mean } \pm \text { SD })\end{array}$ & $\begin{array}{c}\text { T-value } \\
\left(\mathrm{H}_{0}: \begin{array}{c}\text { Mean=Market } \\
\text { Value })\end{array}\right.\end{array}$ & $\mathrm{P}$-Value \\
\hline \multirow{2}{*}{ Protein } & $2.740 \pm 0.0866$ & $11.959^{* *}$ & $\mathrm{P} \leq 0.001$ \\
& $2.792 \pm 0.1706$ & $26.558^{* *}$ & $\mathrm{P} \leq 0.001$ \\
Fat & $4.120 \pm 0.8065$ & $5.195^{* *}$ & $\mathrm{P} \leq 0.001$ \\
& $4.360 \pm 0.7314$ & $3.273^{* *}$ & 0.003 \\
Lactose & $4.040 \pm 0.1581$ & $16.927^{* *}$ & $\mathrm{P} \leq 0.001$ \\
& $4.032 \pm 0.1973$ & $20.871^{* *}$ & $\mathrm{P} \leq 0.001$ \\
SNF & $7.6476 \pm 0.34219$ & $11.959^{* *}$ & $\mathrm{P} \leq 0.001$ \\
& $7.5716 \pm 0.33726$ & $26.558^{* *}$ & $\mathrm{P} \leq 0.001$ \\
\hline Significant at $10 \%$. & &
\end{tabular}

In Table 11, a highly statistical significance was seen between the obtained nutrition levels and accepted standard levels for each type of nutrition categories. Thus, the results generally demonstrate that there is a difference in nutrition levels of obtained samples and the standard nutrition levels of milk. The gross composition of raw milk could be affected by several factors which may include breed of the cow, stage of lactation, feeding, environmental stress, seasonality and adulterations and age of the cow. But these factors were not fully monitored in the study. The milk must have also been collected and analyzed during the early lactation periods accounting for the standard protein content [15].

\section{CONCLUSION}

Milk is a highly perishable commodity. Since milk deteriorates quickly, proper hygienic practices should be followed when handling, storage, and preservation it. In Lankapura area, total bacterial count is higher than the accepted level. To increase efficiency along the milk collection process in Lankapura area, a complete cold chain for the milk sub sector at the source of production should be established.

The overall mean total bacterial count, percent lactic acid of milk produced in the households of study area were $6.193 \pm 0.311 \log 10 \mathrm{CFU} / \mathrm{ml}$ and $0.229 \% \pm 0.029$. The hygienic quality of raw cow's milk of the bulk milk tanks was poor with an overall mean total bacteria count and percent of lactic acid of $6.6427 \pm 0.322 \log 10 \mathrm{CFU} / \mathrm{ml}$ and $0.294 \% \pm 0.020$. All milk samples collected from bulk milk tanks were likely to clot by alcohol test and 56\% milk samples collected from households were clot. In Resazurin test, none of the bulk milk product performed in blue colour for resazurin test, while few household milk productions (12\%) performed in blue colour for resazurin test. Sample in bulk milk production was performed purple colour and purple pink colour for resazurin test, while in most household milk production $(88 \%)$ was performed purple colour for resazurin test. All the in direct tests and actual bacterial counts indicated that the microbiological quality of milk produced by farmers and bulk tanks of the dairy cooperatives in the study area were poor.

The specific gravity of household milk samples was $1.028 \mathrm{~g} / \mathrm{ml}$ and for bulk milk samples, $1.029 \mathrm{~g} / \mathrm{ml}$. The mean percentage of protein, fat, lactose and SNF for bulk milk samples were $2.740 \% \pm 0.0866, \quad 4.120 \% \pm 0.8065$, 
$4.040 \% \pm 0.1581$ and $7.6476 \% \pm 0.34219$ respectively. The mean percentage of protein, fat, lactose and SNF for household's milk samples were $2.792 \% \pm 0.1706$, $4.360 \% \pm 0.7314,4.032 \% \pm 0.1973$ and $7.5716 \% \pm 0.33726$. Specific gravity of the milk samples of study area are lower than the accepted value of the specific gravity of cow milk. $(1.032 \mathrm{~g} / \mathrm{ml})$. According to the results, there is no significant difference was seen between the nutrition condition of bulk milk production and household milk production. In both samples, protein, SNF and lactose levels are lower than the accepted standard levels. But milk fat level is higher than the accepted level.

According to the results obtained during this study on the hygienic quality of raw milk in Lankapura, it indicated that the current milking process required real improvement. In effect, bulk samples had high level of bacteria. The use of proper containers made of stainless steel will reduce this figure even further. The milk can be easily contaminated by different contaminants when it transferred from one container to another, transported to consumers as well as retailers from the production site without cooling facilities, and with no proper milk containers.

Proper milking and milk handling can reduce the microbial contamination of milk. Lack of refrigeration facilities is a main cause of higher microbial load of raw milk. For storage and transportation of milk, refrigeration facilities are essential. The use of unclean milking equipment and lack of portable water for cleaning purpose might have contributed to the poor hygienic quality of the milk. It is that adequate sanitary measures should be practiced at all stages of production to consumption of the milk to protect the milk from spoilage.

According to the results, there is no significant difference was seen between the nutrition condition of bulk milk production and household milk production. In both samples, protein, SNF and lactose levels are lower than the accepted standard levels. But milk fat level is not lower than the accepted level. Nutritive value of milk should be increased by supplying nutritive feed and minerals, prevention of diseases and rearing suitable cattle breeds.

Contaminated milk causes public health risk and therefore hygienic precautions should be taken. Production, transportation, storage, and sale of milk should be done with hygienic practices. Regular monitoring and quality assessment of milk should be performed at those critical control points like collection points and sale counters.

\section{ACKNOWLEDGMENT}

I am so greateful to my supervisor Dr. G.D.D.K Gunasena for her excellent supervision, constructive ideas, and patience for the entire period of this study. I sincerely appreciate your very useful contribution for the accomplishment of this work.

This study would not have materialized, without the support of Mr M.M Gunawardhana, former head of department of microbiology, University of Kelaniya. My thanks should go to Dr Chandani, and staff of Veterinary investigation office at Polonnaruwa for their help during laboratory works.

\section{REFERENCES}

[1] Perera B and Jayasuriya M (2008) The Dairy industry in Sri Lanka, Current status and Future directions for a greater role in national development. Journal of National Science Foundation, Sri Lanka 36 115-126.

[2] Monthly production data, Veterinary surgeon's office, Lankapura, 2018.

[3] Makokha, S. and Fadiga, M.L. (2009): Exploiting markets for dairy and meat products' quality and safety: A Kenyan case study. Research report 24 on Demand for livestock products in developing countries with a focus on quality and safety attributes: Evidence from Asia and Africa.

[4] Cousin MA. Presence and activity of psychrotrophic microorganisms in milk and dairy products. J Food Prot. 1982; 45:172-207.

[5] Orregård, M. 2013a. Quality analysis of raw milk along the value chain of the informal milk market in Kiambu County, Kenya. Swedish. Masters Thesis University of Agricultural sciences.

[6] Tassew, A., \& Seifu, E. (2010). Microbial quality of raw cowes milk collected from farmers and dairy cooperatives in Bahir Dar Zuria and Mecha district, Ethiopia. Agriculture and Biology Journal of North America, 29 to 31.

[7] Yuen, S. K., C. F. Yee, and F. H. Yin. 2012. ISSN 2249-8516 Original Article Microbiological Quality and the Impact of Hygienic Practices on the Raw Milk Obtained from the Small-scale Dairy Farmers in Sabah, Malaysia. Int. J. Agric. Food Sci. 2:55-59.

[8] Street, A., and D. Bogor. 2013. Prevalence and Sources of Contamination of Escherichia coli and Salmonella spp. In Cow Milk Dangke, Indonesian Fresh Soft Cheese Faculty of Veterinary Medicine, Bogor Agriculture University, Glob. Vet. 11:352-356.

[9] O’Connor C B 1994 Rural Dairy Technology. ILRI training manual No. 1. International Livestock Research Institute (ILRI), Addis Ababa, Ethiopia. 133p.

[10] WHO and FAO, 2002.

[11] http://www.lankapura.ds.gov.lk/index.php/en/about-us/overview.html.

[12] Marth E H (Ed.) (1978) Standard Methods for the Examinations of Dairy Products. P. 416. American Public Health Association, Washington DC.

[13] International Dairy Federation (IDF) (1990) Milk Collection in warm developing countries, pp. 57-59. SqureVergote, Brussels, Belgium.

[14] Ramsdell, A, Johnson, W.M.T and Evans, F.R. 1935, Investigation of Resazurin as an Indicator of the Sanitary Condition of Milk, Dairy sciences, volume 18, Issue 11, Pages 705-717.

[15] O'Mahoney, F. (1988). Rural dairy technology-Experiences in Ethiopia. ILCA Manual No. 4. Dairy Technology Unit. ILCA, Addis Ababa, Ethiopia. pp. 64.

[16] Prejit, N., Nanu, E., \& Latha, C. (2011). Microbial quality assurance of milk during production, processing and marketing, American Journal of food Technology, 2(3):136-144.

[17] Nanu, E., Latha, C., Sunil, B., Prejit, N., Thomas, M., \& Menon,K.V.(2007). Quality Assurance and Public Health Safety of Raw Milk at the production point, American Journal of Food Technology, 2: 145-152.

[18] Welearegay, H., Yilma, Z. \& Giorgis, Y.T. (2012). Hygienic practices and microbial quality of raw milk produced under different farm size in Hawassa, Southern Ethiopia, Agricultural Research and Reviews Vol. 1(4):132 - 142.

[19] Donkor E S, Aning K G, Omore A, Nurah G K, Osafo E L K and Staal S (2007) Risk factors in the Hygienic quality of milk in Ghana. The Open Food Science Journal 1 6-9.

[20] Kuma A, Abdisa M and Tolossa D (2015) Evaluation of hygienic status and marketing system of raw cow milk in different critical points of Oromia special zone. Global Journal of Science Frontier Research 15 21-30.

[21] O Connor, C. B. (1995). Rural Dairy Technology. ILRI Training Manual 1. Addis Ababa, Ethiopia: International Livestock Research Institute.

[22] Milk testing and payment system, Resource book, FAO, 2009.

[23] Kurwijila, R. L., Hansen, K. K., Macha, I. E., Abdallah, K. and Kadigi, H. J. S. (1992): The bacteriological quality of milk from hand and machine milked dairy herds in Morogoro, Tanzania. African Livestock Research. 2: 59-67.

[24] Godefay, B., and Molla, B., (2000): Bacteriological quality of raw milk from four dairy farms and milk collection centres in and around Addis Ababa. Berl. Münch. Tierärztl.Wschr. 113:1-3.

[25] Abeygunawardana DI, Ranasinghe RMSBK and Deshapriya RMC, 2017 , Hygienic practices and quality of raw milk produced in a small scale dairy farming area in Sri Lanka, International Journal of Scientific and Research Publications, Volume 7, Issue 7, July 201772 ISSN 2250-3153. 
[26] Vairamuthu S, Sinai J and Agalingam K (2010) Factors Influencing production of Hygienic raw milk by small scale dairy producers in selected areas of Jaffna district. Tropical Animal Health Production 42 357-362.

[27] Senarath H.M. I. G. A. M. K. and Adikari A. M. J. B., 2017, Microbiological Quality of Raw Milk at Selected Chilling Centers in Anuradhapura District of Sri Lanka, International Journal of Scientific and Research Publications, Volume 7, Issue 11, November 2017328 ISSN 2250-3153.

[28] Moon, J. S., YiSeok, J., SukKyung, I., BokGyeong, K., HyunMi, K., GumChan, J., JongMan, K., and OkKyung, K., (2000): Effects on improvement of milk quality after application of payment system by hygienic quality of raw milk from dairy cow in Korea. Korean Journal of Veterinary Public Health. 24(3): 223-229.

[29] Wallace, R. L., (2009): Bacteria count in raw milk. Accessed on 19th June

2012

athttp://www.livestocktrail.illinois.edu/uploads/dairynet/papers/Bacter ia\%20Counts\%20in\%20Raw\%20Milk\%20DD\%202008.pdf.

[30] Abdalla, M.O.M., and Elhagaz, F.M.M., (2011): The impact of applying some hygiene practices on raw milk quality in Khartoum state, Sudan. Research Journal of Agriculture and Biological Sciences. 7 (2):169-173.

[31] Islam T B M M, Summy M, Mandal M N A and Uddin G M N (2013) Rapid estimation of quality of raw milk for its suitability for further processing in dairy industries of Bangladesh. International Journal of Dairy Science 8111.

[32] Milk training guide for small scale informal traders in Kenya (2004): Improve the quality of your milk and please your customers-accessed at

http://www.ilri.org/Link/Publications/Publications/MilkHygieneGuide -Trader.pdf.

[33] Food and Agricultural Organization, (1979): Manuals of Food Quality Control. 4. Microbiological Analysis. FAO, Rome.

[34] Dahal, L.R., Dainik, B., Nepali, K., and Ramashish, S., (2010): Total bacterial counts of raw milk in Eastern Terai of Nepal. The Journal of Agriculture and Environment.11:46-50.

[35] Tammy (2009), milk processing and quality management, society of dairy technology, United Kingdom.

[36] O'Connor, C. B. (1993). Traditional cheese making manual ILCA (Internatinal livestock center for Africa) Addis Ababa, Ethiopia 43pp

[37] http://www.iftbu.org/milk.htm

[38] Young, C. W., J. K. Hillers, and A. E. Freeman. 1986. Production, consumption, and pricing of milk and its components. J. Dairy Sci. 69:272.

[39] Wedholm, A., Larsen, L.B., Lindmark Månsson, H., Karlsson, A.H. \& Andrén, A. (2006). Effect of Protein Composition in the CheeseMaking Properties of Milk from Individual Dairy Cows. Journal of Dairy Science 89, 3296-3305.

[40] Walstra et. al., Dairy science and technology. 2nd ed. 2006.

[41] Tancin, V., Uhrincat, M., Macuhova, L. \& Bruckmaier, R.M. (2007). Effect of pre-stimulation on milk flow pattern and distribution of milk constituents at a quarter level. Czech Journal of Animal Science 52(5), 117-121.

[42] Goff, H.D. and W, A.R. 1993. Chemistry and physics. In Hui, Y.H. (ed.), "Daky Science and Technology Handbook. Volume Y, Chapter 1. VCH Publishers,Inc., New York.

[43] Zinash, S. Seyoum, B. Michalak, B.W. and Teshome, K. (1988). Observations on the fat and protein contents of the milk of crossbred and local cows. In: Proceedings of the second National Livestock Improvement Conference, 24-26 February, Addis Ababa Ethiopia. Pp. 124-126.

[44] Vanden Berg, J. C. T. (1988). Dairy Technology in the tropic and subtropics. Center for Agricultural Publishing and Documentation (Pudoc). Wagneningen, the Netherlands, 290pp.

[45] Suman CL,Sexana MM, Pandy HS, Dubey PC,Rajendra s, Sanyal MK(1998), Some factors affecting milk constituents yield of murah buffalo. Indian vet. J 75(2). 176- 177.

[46] https://www.quora.com.

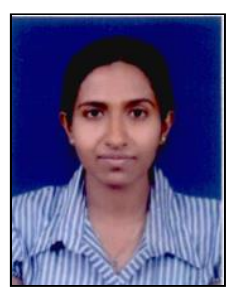

B. A. M. P. Siriwardhana was born in Polonnaruwa, Sri Lanka on $1^{\text {st }}$ of May 1983. She has been involved with studies related to Veterinary medicine and animal science in University of Peradeniya., 2010. She is qualified with MSc in food and nutrition at the University of Kelaniya, 2018. Author is working as a Government veterinary surgeon, Polonnaruwa.

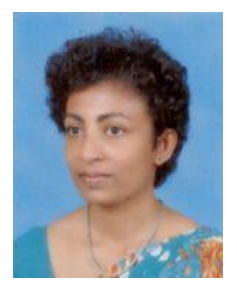

Dr. (Mrs.) Deepthi K. Gunesena is Senior Lecturer, Department of Microbiology,Faculty of Science, University of Kelaniya, Kelaniya 11600, Sri Lanka. She has completed her $\mathrm{PhD}$ in bacterial pathogenesis at the University of Reading, UK and BSc in Microbiology, at the University of Kelaniya, Sri Lanka. She is attached to the Department of Microbiology, Faculty of Science, University of Kelaniya, Sri Lanka as a senior lecturer. Her research interests mainly focus on beneficial bacteria in Food and pathogenic bacteria in food. 